A look at the region

\title{
Hic sunt leones? The Morava Valley Region During the Early Middle Ages: The Bilateral Mobility Project between Slovakia and Austria
}

\author{
Mária Hajnalováa ${ }^{*}$, Stefan Eichert ${ }^{\mathrm{b}}$, Jakub Tamaškovič ${ }^{\mathrm{a}}$, Nina Brundke ${ }^{\mathrm{b}}$, Judith Benedix ${ }^{\mathrm{b}}$, \\ Noémi Beljak Pažinováa , Dominik Repka ${ }^{a}$ \\ ${ }^{a}$ Department of Archaeology, Faculty of Arts, Constantine the Philosopher University in Nitra, Štefánikova 67, 94974 Nitra, Slovakia \\ ${ }^{b}$ Department of Prehistory and Historical Archaeology, Faculty of Historical and Cultural Studies at the University of Vienna, \\ Franz-Klein-Gasse 1, 1190 Wien, Austria
}

\section{ARTICLE INFO}

\section{Article history:}

Received: $25^{\text {th }}$ January 2017

Accepted: $20^{\text {th }}$ June 2017

DOI: http://dx.doi.org/ 10.24916/iansa.2017.1.7

Key words:

bilateral project

Early Medieval Period

Slovakia

Austria

cross-border cooperation

\begin{abstract}
$A B S T R A C T$
Cross-border cooperation is very important for understanding the cultural-historical development of the border regions of modern day states. These areas, today, are often considered as "peripheries". However, in the past they usually had a very different function and status. This article introduces one bilateral mobility project between the archaeological departments at the University of Vienna and the Constantine the Philosopher University in Nitra, aimed at facilitating more focused early medieval archaeological research in the region along the lower stretches of the Morava River. The article introduces the region, its history and state of research and describes the role of the project, the team and the project results obtained up to date.
\end{abstract}

\section{Introduction}

"Hic sunt leones" is a two-year bilateral mobility project for the years 2016-2017 between the University of Vienna, Institute of Prehistory and Historical Archaeology (principal investigator Stefan Eichert) and the Constantine the Philosopher University in Nitra, Department of Archaeology in the Faculty of Arts (principal investigator Mária Hajnalová). The project aims to investigate the historical development of the border region between Austria and Slovakia during the Early Middle Ages, a time period from the sixth century $\mathrm{AD}$ to the eleventh century AD. Scientifically, the goal is to create a homogenous state of the art research milieu that scholars from both countries will benefit from.

\section{State of research}

Archaeological research in southwest Slovakia and northeast Austria has resulted in several publications concerned

*Corresponding author. E-mail: mhajnalova@ukf.sk with the cultural and historical developments of the early medieval period, but all are based on data almost exclusively either from Slovakia or from Austria (cf. Bednár 2001; 2013; Fusek 2008; Herold 2007; 2010, 153-166; Justová 1990; Pollak 2009; Repka 2011; Ruttkay 1996; Ruttkay 2006; Wawruschka 2009) and almost never geared toward transregional comparison or data correlation. A closer look at the available scholarly information shows that the social and cultural history, palaeoeconomy and paleoecology of the Lower Morava valley region remain a "terra incognita".

Until the early 1990s, research was strongly limited by the historical geo-political divides in the region. Cooperation across the Iron Curtain was barely possible. Unfortunately, despite the much more favourable political climate, the situation has not changed much since 1989. As a result, archaeological sites have been researched using different approaches and methodologies. They are described and evaluated employing different chronological and typological terminologies on both banks of the lower course of the Morava River.

Furthermore, our present knowledge is heavily biased by the long-standing focus on fortified "central" settlements to the neglect of much commoner, smaller, rural locales 


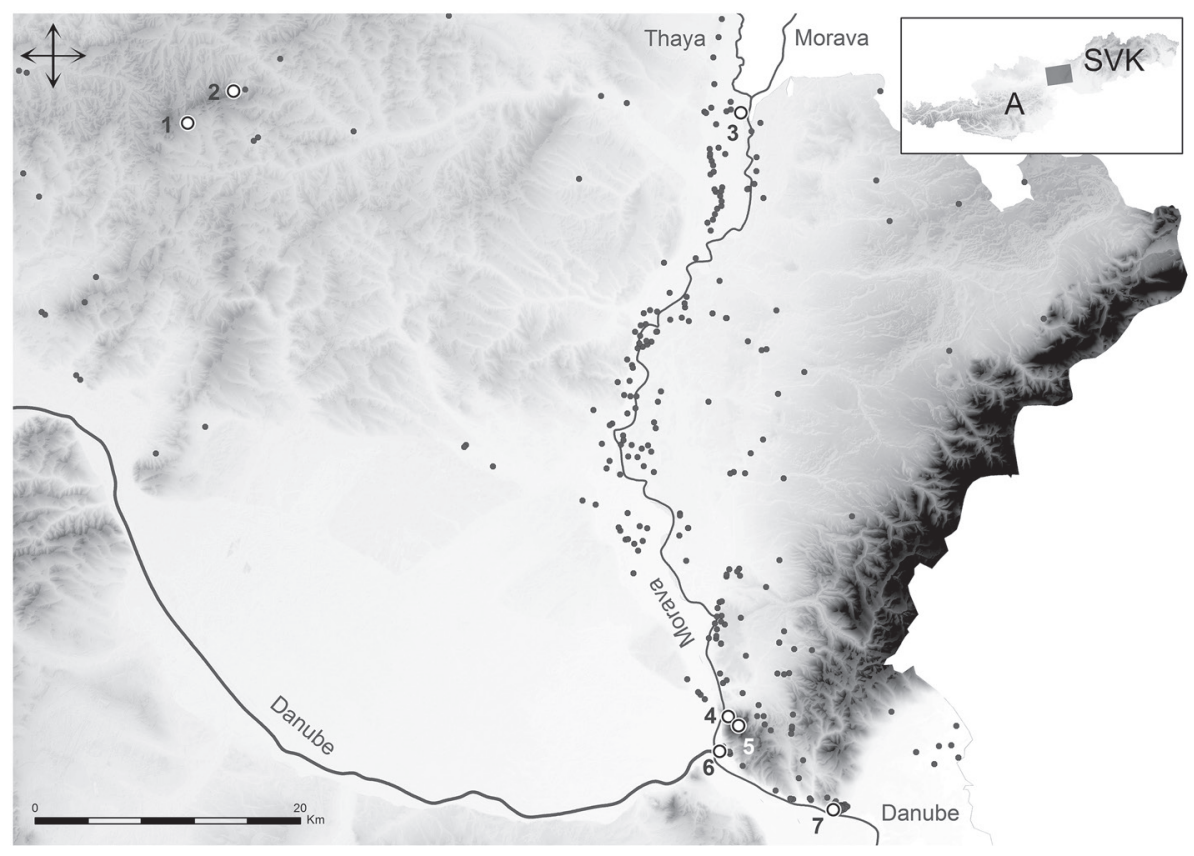

Figure 1. The study region in the Marchfeld-Záhorie area. 1. Oberleiserberg, 2. Michelstetten, 3. Hohenau, 4. Devínska Nová Ves - Nad Lomom, 5. Devínska Nová Ves - Na Pieskach, 6. Bratislava - Devín, 7. Bratislava - Hradný vrch; small dots other early medieval sites with information available in published sources. (cf. Herold 2011; 2012; 2016; Henning, Ruttkay 1998; 2011; Macháček 2013; Ruttkay 2012; 2015). For these and other reasons, the cultural landscape and the early medieval settlement structure of the lower Morava River have never been researched as a single entity - a complex system consisting of various types of settlements and burial grounds.

\section{The region under study}

Geographically, the studied area belongs to the Vienna Basin. The central axis is formed by the lower course of the Morava River. In Slovakia, the area covers the southern part of the Záhorie region (Bor Lowlands) - the territory between the river and the Lower Carpathians, delimited by the Myjava River to the north and the area of Bratislava to the south. In Austria, it covers the adjacent parts of the Marchfeld (Figure 1).

While the region's medieval material culture (e.g. ceramics and metal finds) is relatively uniform on both sides of the river, the natural environment differs. The lower elevations in both countries are covered by the level floodplains of the Morava River and its tributaries. The elevated, upland areas in Austria represent the stable loess hills of the rolling landscape of Weinwiertel. In Slovakia, almost half of the study region is covered by unstable dunes of eolithic sands (Fordinál 2012; Kalivodová et al. 2008, 10) that form a highly specific and unique environment. These differences in geology are mirrored in different soil types and vegetation.

\section{A brief history of the region}

In the sixth and seventh century $\mathrm{AD}$, Slavs settled and established new communities on the territory of what is now the Austrian, Slovakian and Moravian side of the Morava River (Fusek 2013; Fusek, Zábojník 2003). In the vicinity of Bratislava, in the southern part of the study region, there is a strong evidence for probably peaceful interactions between Slavs and Avars (Bialeková, Zábojník 1996; Herold 2010; 2014; Winter 1997; Zábojník 1989; 2009). Further to the west and north along the Morava River, the evidence for Avaric influence declines (Zábojník 1999).

At the beginning and first half of the eighth century AD, the dichotomy between the development of the areas east and west of the Morava River seems to have grown. The eastern part (now in Slovakia) most probably fell under the political influence of the Moravian Principality (Ruttkay 2008, 269-270), while the western part (now in Austria) was gradually incorporated into the realm of Emperor Charlemagne. He used the Danube River and adjacent lands as a route and base for his military expeditions against the Avars (Zábojník 2009, 10-13).

Later, during the late eighth and start of the ninth century $\mathrm{AD}$, the area on both sides of the river seems to have transformed into a buffer zone between the Carolingian Empire, the Moravian Principality and the Principality of Nitra. After the principalities of Moravia and Nitra merged in the ninth century with the conquest of Mojmír I in the Moravian Empire, the region became a contact and, at the same time, a frontier zone of the Carolingian Empire. The life of the people living here in those times was most probably strongly influenced by several military conflicts that lasted for over half a century (Musilová 2012; Steinhübel 2012a, 310-312).

At the beginning of the tenth century, the area witnessed the collapse of the Great Moravian Empire and the raids from tribes of "Old Hungarians" (Révész 2014; Vavruš 2008; Staššíková-Štukovská 2008). During the 
first decades of the tenth century and up to the eleventh century, the western side of the Morava River (today in Austria) transformed into a border/buffer zone between the newly-arriving Hungarians and the already, by then, "autochthonous" Slavic populations (Štefanovičová 2008, 139-146). Life in the region of Bratislava seems to have continued without interruption and with no indication in the archaeological evidence of any catastrophic events (Goldberg 2004; Štefanovičová 2012, 336). Bratislava became a political centre and the seat of a "comitatus" of the Hungarian kingdom (Steinhübel 2012b). The situation was very different north-west of Bratislava. The region at the confluence of the Morava and Dyje Rivers (March/ Thaya) and central Moravia witnessed a discontinuity in development. The collapse of the Great Moravian central sites is manifested in the archaeological record (Kouril 2008; Macháček, Wihoda 2013; Štefan 2011, 344-348). Later, during the eleventh century, the region developed into a zone of interaction between Přemyslid Moravia, Árpád Hungary and the Babenberg March.

During the first decades of the eleventh century, the region of Bratislava fell under the control of the kingdom of Poland (Steinhübel 2012b, 363). From the middle of the eleventh to the thirteenth century, the Záhorie Region literally turned into a "no man's land". It was purposely depopulated, and the area known as a "confinium" again served as a "buffer zone" between territory of the Árpád dynasty and its neighbours ( $c f$. Hladík 2014, 61; Janšák 1960).

Due to the absence of focused archaeological research in this study region, it remains unclear on what scale, and how much, the historical events described above and the differences in the natural environment east and west of the Morava River have influenced the life of the people, their settlement and subsistence strategies.

\section{The project role, aims and goals}

The main role of the project is to find the most effective ways and methods to enable researchers to use and visualise the majority of the already-existing archaeological and environmental data which would help to minimise the existing biases.

This goal is being achieved by collecting as much data as possible from archaeological sites and "findspots", describing and classifying them using a common terminology and chronology as well as organizing and storing them together in a single database.

The plan is that the collected data will be released as open data and made available for a wider audience, even after the project has reached completion. As such, scholars will be able to carry out multiple, joint cross-border analyses which to date has not been possible. Among other things, after the transformation of cross-regional data to formats more suitable for statistical analyses, GIS ( $c f$. Demján, Dreslerová 2016; Dresler, Macháček 2013; Hladík 2014,
72-110; Kamermans et al. 2009; Lieskovský et al. 2013; Verhagen, Whitley 2012; Verhagen et al. 2013; Verhagen et al. 2016) and agent-based modelling (Danielisová, Štekerová 2015; Wurzer et al. 2015), it will be possible to draw a more realistic picture of the cultural-historical and economic development of the area along the lower stretches of the Morava/March River during the period from the sixth to the eleventh century AD.

\section{Project team}

At present, the team is formed by six young researchers (Doctoral and Master students): Jakub Tamaškovič from Nitra, Nina Brundke, Judith Benedix, Edith Nechansky and Karin Kühtreiber from Vienna, two university lecturers: Stefan Eichert from Vienna and Dominik Repka from Nitra and finaly two associate professors Noémi Beljak Pažinová and Mária Hajnalová from Nitra. Their research specialisations are supplementary, but also partly overlap. Edith Nechansky specialises in pottery analyses and Karin Kühtreiber in settlement archaeology and the archaeology of medieval castles. Dominik Repka specialises in pottery analyses and in the archaeology of medieval nobility seats. Nina Brundke is an osteoarchaeologist and palaeopathologist, and Judith Benedix is an archaeologist and anthropologist. Jakub Tamaškovič is a field excavator and uses correlations between various types of geographical (soils, geomorphology, vegetation, etc.), ecological (vegetation, water availability), and archaeological data in GIS as a tool for the study of past settlement patterns and land-use strategies. Mária Hajnalová is an archaeobotanist and palaeoecologist. Noémi Beljak Pažinová specialises in archaeological methodology, and Stefan Eichert is an expert on database design and digital humanities.

Travel expenses to the partner universities, where topic oriented round tables and workshops were organized by the project partners, were funded by this project. More details on the project and each team member can be found at the project website: http://homepage.univie.ac.at/stefan. eichert/gkn/index.php/themen/hicsuntleones.

\section{Cooperation}

The project members are involved in other programmes that investigate the role of the "border region" along the Morava River valley and other local early medieval realia. This is on the Austrian side the FWF and GAČR funded international project "Frontier, Contact Zone or No Man's Land?" (I 1911, G21; Principal investigator Stefan Eichert, University of Vienna and Jiři Macháček, Masaryk University, Brno; see also http://homepage.univie.ac.at/ stefan.eichert/gkn). In addition, there is a cooperation with members of the Institute of Archaeology of the Academy of Sciences of Czechia regarding the fortified settlement of Mikulčice and its hinterland (Marek Hladík). 


\section{Project results up to date}

The project is still on-going and it is at the half-way point. The originally expected results of the project scheme - the consolidation of scientific networks and dissemination of existing knowledge - were successfully met in the first year. In addition, exchange visits were used to produce tangible scientific results.

Firstly, after consulting material culture data during the workshops, we have established a common terminology for the classification and categorization of archaeological sites, features and finds - as well as for their attributes. One of the first results is an English language thesaurus that is structured hierarchically. The parent-child relationships between categories allow for a high compatibility on the top levels of classification and at the same time for individualised specifications on a detailed level (Figure 2).

Secondly, we have negotiated a common chronological scheme, applicable to both regions and compatible with the scheme used in the Czech Republic - the third country in the lower Morava River region. Each country in the region uses its own national "system". Often the time periods are defined by ethnic or political labels such as "Late Avar Period" or "Hungarian Kingdom". However the ethnic and political situation in the three neighbouring countries was not homogenous during the Middle Ages and the chronological schemes often aim only at a single region or population. We have thus focused on "neutral timespans" that, in the next step, can be correlated with national chronologies (for up to date chronological schemes see: Eisner 1966; Fusek,

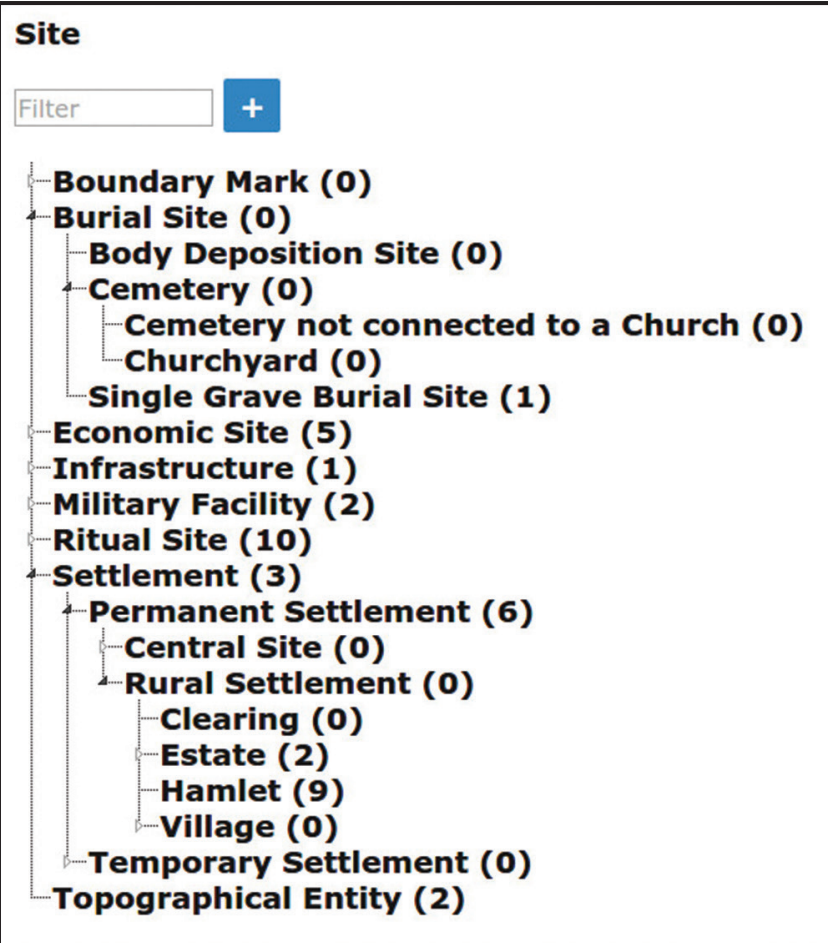

Figure 2. Screenshot of the Open Atlas User interface showing the hierarchical structure of types/categories for sites.
Zábojník 2003; Zábojník 2009; Hanuliak 2004; Stadler 2005).

Thirdly, the common regional terminology and chronological scheme are being used within the project as a basic tool for the effective synchronization and arrangement of the Early Medieval archaeological data and material culture from the region. With these conceptual foundations we have begun to record our data in a common database using the Open Atlas system (Eichert 2014; http://openatlas.eu). The common data model is based on the CIDOC-CRM, an established conceptual reference model especially developed for cultural heritage documentation (http://www.cidoc-crm. org/). Within this framework we use hierarchically-organized types to classify our data.

Fourthly, we have ascertained that the open environmental data on soils, geomorphology, hydrology, etc., available in Austria (www.data.gv.at) are not sufficiently detailed for a GIS analysis of the relationship between settlement and environment and that environmental data of much higher detailed resolution have to be obtained (Tamaškovič et al. 2017).

Fifthly, the team has begun a collaboration with the international project "Digitizing Patterns of Power" (http://dpp.oeaw.ac.at) for which we are preparing (the work being still in progress) an open access environment for communicating various types of archaeological and historical data from the region under study. Lastly, but by no means the least, data are being put into and stored in digital layers, permitting their analysis using various methods and their visualisation for a wider (not only scholarly) audience.

\section{Acknowledgments}

This project is funded by the Slovak Research and Development Agency (SRDA), project no. SK-AT-2015-0012, and the OeAD (Austrian agency for international mobility and cooperation in education, science and research), project na SK 05/2016.

\section{References}

BEDNÁR, P. 2001: Sídlisková štruktúra Nitry v 9. storočí. In: Galuška, L., Kouřil, P., Měřinský, Z. (Eds.): Velká Morava medzi východem a Západem. Großmähren zwischen West und Ost. Spisy Archeologického ústavu AV ČR Brno 17. Brno, 29-40.

BEDNÁR, P. 2012: Nitra v časoch pôsobenia sv. Konštantína - Cyrila a sv. Metoda. In: Panis, B., Ruttkay, M., Turčan, V. (Eds.): Bratia ktori menili svet - Konštantín a Metod. Príspevky z konferencie. Nitra, 145-156.

BIALEKOVÁ, D., ZÁBOJNÍK, J. 1996: Etnische und kulturelle Verhältnisse an der mittleren Donau vom 6. bis 11. Jahrhundert: Symposium Nitra 6. bis 10. November 1994. Bratislava.

DANIELISOVÁ, A., ŠTEKEROVÁ, K. 2015: Sociální simulace při zkoumání společnosti, ekonomiky a využití krajiny $\mathrm{v}$ době železné: metody a př́klady. Památky archeologické, 106, 137-180.

DEMJÁN, P., DRESLEROVÁ, D. 2016: Modelling distribution of archaeological settlement evidence based on heterogeneous spatial and temporal data. Journal of Archaeological Science 69, 100-109.

DRESLER, P., MACHÁČEK, J. 2013: Vývoj osídlení a kulturní krajiny 
dolního Podyjí v raném středověku. Archeologické rozhledy 65/4, 663-705. EICHERT, S. 2014: OpenATLAS - An Open Source Database Application for Archaeological, Historical, and Spatial Data. Museum der Stadt Wien - Stadtarchäologie, Proceedings of the $18^{\text {th }}$ International Conference on Cultural Heritage and New Technologies 2013, CHNT 18.Vienna.

EISNER, J. 1966: Rukovět' slovanské archeologie: Počátky Slovanú a jejich kultury. Praha.

FORDINÁL, K. 2012: Vysvetlivky ku geologickej mape Záhorskej nižiny Bratislava 2012.

FUSEK, G. 2008: Osídlenie Nitry v 10. storočí. Kontinuita alebo diskontinuita? In: Štefanovičová, T., Hulínek, D. (Eds.): Bitka pri Bratislave roku 907 a jej význam pre vývoj stredného Podunajska. Bratislava, 295-304.

FUSEK, G. 2013: Beitrag zur Problem der Datierung von der Besiedlung der Westslowakei in der älteren Phase des Frühmittelalters. In: Dulinicz, M., Moździoch, S. (Eds.): The Early Slavic Settlement of Central Europe in the light of new dating evidence. Interdisciplinary Medieval Studies III. Wroclaw, 139-150.

FUSEK, G., ZÁBOJNÍK, J. 2003: Príspevok do diskusie o počiatkoch slovanského osídlenia Slovenska. Slovenská Archeológia 51/2, 319-340.

GOLDBERG, E. J. 2004: Ludwig der Deutsche und Mähren. Eine Studie zu karolingischen Grenzkriegen im Osten. In: Hartmann, W. (Ed.): Ludwig der Deutsche und seine Zeit. Darmstadt, 67-94.

HANULIAK, M. 2004: Vel'komoravské pohrebiská: Pochovávanie v 9.-10. storoči na územi Slovenska. Nitra.

HEROLD, H. 2007: Die Besiedlung Niederösterreichs im Frühmittelalter In: Zehetmayer, R. (Ed.): Schicksalsjahr 907. Die Schlacht bei Pressburg und das frühmittelalterliche Niederösterriech. St. Pölten, 77-91.

HEROLD, H. 2010: Zillingtal (Burgenland) - Die awarenzeitliche Siedlung und die Keramikfunde des Gräberfeldes. Teil 1. Monographien des Römisch-Germanischen Zentralmuseums, Band 80. Mainz.

HEROLD, H. 2011: The fortified hilltop site of Gars-Thunau and the settlements of the $9^{\text {th }}$ and $10^{\text {th }}$ centuries in Lower Austria. In: Macháček, J., Ungerman, Š. (Eds.): Frühgeschichtliche Zentralorte in Mitteleuropa. Studien zur Archäologie Europas, Band 14. Bonn, 519-528.

HEROLD, H. 2012: Fortified Settlements of the $9^{\text {th }}$ and $10^{\text {th }}$ Centuries $\mathrm{AD}$ in Central Europe: Structure, Function and Symbolism. Medieval Archaeology 56, 60-84

HEROLD, H. 2014: Insights into the chronology and economy of the Avar Kaganate and the Post-Avar period: Pottery Production and use in the Carpathian Basin from the late $6^{\text {th }}$ to the $10^{\text {th }}$ century AD. Acto Archaeologica Carpathica, 49, 207-229.

HEROLD, H. 2016: The Natural Environment, Anthropogenic Influences and Supra-Regional Contacts at $9^{\text {th }}-$ to $10^{\text {th }}$ Century Fortified Elite Settlements in Central Europe. In: Christie, N., Herold, H. (Eds.) Fortified Settlements in Early Medieval Europe. Defended Communities of the $8^{\text {th }}-10^{\text {th }}$ Centuries. Oxford - Philadelphia, 107-120.

HENNING, J., RUTTKAY, A. 1998: Frühmittelalterlicher Burgenbau in Mittel- und Osteuropa. Bonn.

HENNING, J., RUTTKAY, M. 2011: Frühmittelalterliche Burgwälle an der mittleren Donau im ostmitteleuropäischen Kontext: Ein deutschslowakisches Forschungprojekt. In: Macháček, J., Ungerman, Š. (Eds.) Frühgeschichtliche Zentralorte in Mitteleuropa. Studien zur Archäologie Europas, Band 14. Bonn, 259-288.

HLADÍK, M. 2014: Hospodárske zázemie Mikulčic. Sídelná štruktúra na strednom toku rieky Morava v 9. - 1. polovici 13. storočia. Brno.

JANŠÁK, Š. 1960: Konfínium na Záhorí a stará cesta ním vedúca z Bratislavy do Prahy. Geografický časopis 12, 86-96.

JUSTOVÁ, J. 1990: Dolnorakouské Podunaji v raném středověku. Slovanská archeologie k jeho osídleni v 6. - 11. století. Praha 1990.

KALIVODOVÁ, E. et al. 2008: Flóra a fauna viatych pieskov Slovenska. Bratislava

KAMERMANS, H., VAN LEUSEN, M., VERHAGEN, P. 2009: Archaeological Prediction and Risk Management. Alternatives to Current Practice. Archaeological Studies Leiden University 17. Leiden.

KOUŘIL, P. 2008: Archeologické doklady nomádskeho vlivu a zásahu na území Moravy v závěru 9. a v 10. století. In: Štefanovičová, T., Hulínek, D. (Eds.): Bitka pri Bratislave v roku 907 a jej význam pre vývoj Stredného Podunajska. Bratislava, 113-136.

LIESKOVSKÝ, T., ĎURIAČKOVÁ, R., KARELL, L. 2013: Selected Mathematical Principles of Archaeological Predictive Models Creation and Validation in the GIS Environment. Interdisciplinaria Archaeologica Natural Sciences in Archaeology IV/2/2013, 177-190.

MACHÁČEK, J. 2013: Great Moravian Central Places and their practical function, social significance and symbolic meaning. In: Ettel, P., Werther, L. (Eds.): Zentrale Orte und zentrale Räume des frühmittelalters in Süddeutschland. Mainz, 235-248.

MACHÁČEK, J., WIHODA, M. 2013: Dolní Podyjí medzi Velkou a přemyslovskou Moravou. Archeologicko - historická interpretace výsledků interdisciplinárního výzkumu z let 2007 - 2012. Archeologické rozhledy $65,878-894$.

MUSILOVÁ, M. 2012: Okolie Bratislavy vo vel'komoravskom období. In: Šedivý, J., Štefanovičová, T. (Eds.): Dejiny Bratislavy 1. Brezalauspurc na križovatke kultúr. Odpočiatkov do prelomu 12. až 13. storočia. Bratislava, 346-347.

POLLAK, M. 2009: Frühgeschichtliche Siedlungen an der Unteren March, Niederösterreich - Kontinuität einer Kulturlandschaft. Přehledy výzkumu 50, 153-179.

REPKA, D. 2011: Včasnostredoveké osídlenie Spiša. Analýza osídlenia a kritika stavu bádania. Musaica 27, 107-129.

RÉVÉSZ, L. 2014: The Era of the Hungarian Conquest. Budapest.

RUTTKAY, A. 2006: Významné archeologické lokality z včasného stredoveku v oblasti Považského Inovca. In: Pieta, K., Ruttkay, A. Ruttkay, M. (Eds.): Bojná. Hospodárske a politické centrum Nitrianskeho kniežatstva. Nitra, 191-204.

RUTTKAY, A. 2008: Poznámky k etnickému, politickému a kultúrnemu vývoju na území Slovenska v 9. - 13. storočí a vzt’ahom k územiu Moravy. In: Galuška, L., Kouřil, P., Mitáček, J. (Eds.): Východni Morava v 10. až 14. století. Brno, 269-281.

RUTTKAY, M. 1996: Western Slovakia settlement evolution in the $6^{\text {th }}-12^{\text {th }}$ centuries. Ruralia I. Památky archeologické - supplementum 5, 277-281.

RUTTKAY, M. 2012: Mocenské centrá Nitrianskeho kniežatstva. In: Panis, B., Ruttkay, M., Turčan, V. (Eds.): Bratia ktorí menili svet-Konštantín a Metod. Príspevky z konferencie. Nitra, 115-144.

RUTTKAY, M. 2015: Využitie leteckej prospekcie a skenovania pri výskume hradísk a ich zázemia na západnom Slovensku. In: Pieta, K., Robak, Z. (Eds.): Bojná 2. Nové výsledky výskumov včasnostredovekých hradisk. Nitra.

STADLER, P. 2005: Quantitative Studien zur Archäologie der Awaren I. Mitteilungen der Prähistorischen Kommission 60, Wien.

STAŠŠÍKOVÁ-ŠTUKOVSKÁ, D. 2008: Odraz politicko - spoločenského vývoja $\mathrm{v} 10$. storočí na pohrebiskách stredného Podunajska. In: Štefanovičová, T., Hulínek, D. (Eds.): Bitka pri Bratislave v roku 907 a jej význam pre vývoj Stredného Podunajska. Bratislava, 279-294.

STEIHÜBEL, J. 2012a: Vel'komoravské hrady Devín a Preslava. In: Šedivý, J., Štefanovičová, T. (Eds. ): Dejiny Bratislavy 1. Brezalauspurc na križovatke kultúr. Od počiatkov do prelomu 12. až 13. storočia. Bratislava, 309-313.

STEIHÜBEL, J. 2012b: Bratislava ako centrum uhorského komitátu. In: Šedivý, J., Štefanovičová, T. (Eds. ): Dejiny Bratislavy 1. Brezalauspurc na križovatke kultúr. Od počiatkov do prelomu 12. až 13. storočia. Bratislava, 370-374.

ŠTEFAN, I. 2011: Great Moravia, Statehood and Archaeology. The "Decline and Fall" of One Early Medieval Polity. In: Macháček, J., Ungerman, Š. (Eds.): Frühgeschichtliche Zentralorte in Mitteleuropa. Studien zur Archäologie Europas 14. Bonn, 333-354.

ŠTEFANOVIČOVÁ, T. 2008: Slovensko v 10. storočí. In: Štefanovičová, T., Hulínek, D. (Eds.): Bitka pri Bratislave v roku 907 a jej význam pre vývoj Stredného Podunajska. Bratislava, 137-148.

ŠTEFANOVIČOVÁ, T. 2012: Južné podhradie Bratislavského hradu v 8. až 11. stor. In: Šedivý, J., Štefanovičová, T. (Eds. ): Dejiny Bratislavy 1. Brezalauspurc na križovatke kultúr. Od počiatkov do prelomu 12. až 13. storočia. Bratislava, 332-336.

TAMAŠKOVIČ, J., EICHERT, S., HAJNALOVÁ, M., BELJAK PAŽINOVÁ, N., REPKA, D. 2017: Hic sunt leoes? Povodie rieky Moravy vo včasnom stredoveku. In: Hajnalová, M., Beljak Pažinová, N., Šimunková, K. (Eds): Kniha abstraktov. 13. konferencia environmentálnej archeológie: "Človek a krajina”. 6.-7. 2. 2017, Nitra, 73-74.

VAVRUŠ, J. 2008: Prvá mad’arská generácia v archeologických a písomných prameňoch. In: Štefanovičová, T., Hulínek, D. (Eds.): Bitka pri Bratislave v roku 907 a jej význam pre vývoj Stredného Podunajska. Bratislava, 183-195. 
VERHAGEN, P., WHITLEY, T. G. 2012: Integrating Archaeological Theory and Predictive Modeling: A Live Report from the Scene. Journal of Archaeological Method and Theory 19/1, 49-100.

VERHAGEN, P., NUNINGER, L., TOURNEIX, F. P., BERTONCELLO, F., JENESON, K. 2013: Introducing the Human Factor in Predictive Modelling: A Work in Progress. In: Earl, G., Sly, T., Chrysanthi, P. (Eds.) Archaeology in the Digital Era. CAA Series Computer Applications and Quantitative Methods in Archaeology. Amsterdam, 379-388.

VERHAGEN, P., VOSSEN, I., GROENHUIJZEN, M. R., JOYCE, J. 2016: Now you see them, now you don't: Defining and using a flexible chronology of sites for spatial analysis of Roman settlement in the Dutch river area. Journal of Archaeological Science: Reports 10: 309-321.

WINTER, H. 1997: Awarische Grab- und Streufunde aus Ostösterreich: Ein Beitrag zur Siedlungsgeschichte. Innsbruck.
WAWRUSCHKA, C. 2009: Frühmittelalterliche Siedlungsstrukturen in Niederösterreich. Mitteilungen der Prähistorischen Kommission 68. Wien.

WURZER, G., KOWARIK, K., RESCHREITER, H. 2015: Agent-based Modelling and Simulation in Archaeology. Advances in Geographic Information Science Series. Berlin.

ZÁBOJNÍK, J. 1989: Zur Frage der kontakte der nördlichen Peripherie des awarischen Kaganats mit den westlichen Gebiete. Wosinski Mór múzeum évkönyve 15, 103-111.

ZÁBOJNÍK, J. 1999: Das Awarische Kaganat und die Slawen an seiner nördlichen Peripherie. Probleme der archäologischen Abgrenzung. Slovenská archeológia 47/1, 153-173.

ZÁBOJNÍK, J. 2009: Slovensko a avarský kaganát, 2. prepracované a doplnené vydanie, Bratislava. 